\title{
Effect of finishing and polishing methods on surface roughness of autopolymerized acrylic resins
}

Efeito de métodos de acabamento e polimento sobre a rugosidade superficial de resinas acrílicas autopolimerizáveis

Gabriel Lúcio Calazans DUARTE

Angélica Kercya Pereira de MENDONÇA'

Ana Roberta Assunção de FREITAS'

Antônio Ricardo Calazans DUARTE'

Julita de Campos Pipolo HOLANDA ${ }^{1}$

\section{ABSTRACT}

\section{Objective}

To evaluate the surface roughness of two makes of autopolymerized acrylic resin (Classic Dencor ${ }^{\circledR}$ and Duralay ${ }^{\circledR}$ ) with two different methods of finishing and polishing (conventional and using the Dhpro ${ }^{\circledR}$ finishing \& polishing kit).

\section{Methods}

A total of 20 specimens (10 of each make) was obtained using Zetalabor ${ }^{\circledR}$--Zhermak condensation silicone molds. After polymerization, 20 blocks of resin were divided in two and subjected to two types of finishing and polishing, one at each end. The types of finishing and polishing were as follows: conventional (lathe) and using the Dhpro ${ }^{\circledR}$ finishing \& polishing kit. Once finished and polished, the specimens were subjected to surface roughness testing using a roughness meter and were analyzed via the Student's t-test.

\section{Results}

There is a statistically significant difference between the forms of polishing, unrelated to the brand of acrylic resin. Conventional polishing achieved a level of $0.12 \mu \mathrm{m}$ for both resins and the DhPro ${ }^{\circledR}$ polishing presented roughness a little above $0.2 \mu \mathrm{m}$.

\section{Conclusion}

Conventional polishing is superior to the DhPro ${ }^{\circledR}$ kit, as it achieves lower levels of roughness. There is no significant difference between the acrylic resins in terms of surface roughness after the finishing and polishing processes.

Indexing terms: Acrylic resins. Dental polishing. Esthetics, dental.

\section{RESUMO}

\section{Objetivo}

Avaliar a rugosidade superficial de duas marcas de resina acrílica autopolimerizável (Clássico Dencor ${ }^{\circledR}$ e Duralay ${ }^{\circledR}$ ) com dois diferentes métodos de acabamento e polimento (convencional e através do kit de acabamento e polimento da Dhpro ${ }^{\circledR}$.

\section{Métodos}

Um total de 20 corpos de prova (10 de cada marca) foi obtido através de moldes em Silicona de Condensação Zetalabor ${ }^{\circledR}$ - Zhermak. Após a polimerização, os 20 blocos de resina foram divididos ao meio e submetidos a dois tipos de acabamento e polimento, um em cada extremo. Os tipos de acabamento e polimento foram: convencional (em torno mecânico) e através do kit de acabamento e polimento da Dhpro ${ }^{\circledR}$. Após acabados e polidos, os corpos de prova foram submetidos ao ensaio de rugosidade superficial através de um Rugosímetro e analisados por meio do teste " $\mathrm{t}$ " de Student.

\section{Resultados}

Existe diferença significativamente estatística entre os polimentos, não relacionada à marca da resina acrílica. O polimento convencional atingiu um nivel de 0,12 $\mu \mathrm{m}$ em ambas as resinas e o polimento da DhPro ${ }^{\circledR}$ apresentou rugosidade um pouco acima de 0,2 $\mu \mathrm{m}$.

\section{Conclusão}

O polimento convencional é superior ao kit $\mathrm{DhPro}^{\circledR}$, por atingir níveis de rugosidade mais baixos. Não existe diferença significativa entre as resinas acrílicas quanto à rugosidade superficial após os processos de acabamento e polimento.

Termos de indexação: Resinas acrílicas. Polimento dentário. Estética dentária.

\footnotetext{
${ }^{1}$ Universidade Federal do Rio Grande do Norte, Centro de Ciências da Saúde, Departamento de Odontologia. Av. Sen. Salgado Filho, 1787, Lagoa Nova, 59056-000, Natal, RN, Brasil. Correspondência para / Correspondence to: GLC DUARTE. E-mail: <gabriel7duarte@gmail.com>
} 


\section{INTRODUCTION}

Acrylic resin is one of the most widely used dental materials for fabricating dental prostheses ${ }^{1}$. The transitional phase is of great importance to prosthetic treatment as it deals with the simulation of the definitive prosthesis ${ }^{2}$. This material is composed of a liquid-powder system in which the powder is composed of methyl polymethacrylate (polymer) and the liquid is composed of methyl methacrylate (monomer). There are two types of acrylic resin: autopolymerizing (or chemically activated) and heat-polymerizing (heat-activated).

The type of acrylic resin processing can affect the mechanical properties and surface roughness. The polymerized acrylic resin structure has a number of free monomers between $3 \%$ and $5 \%$ in the autopolymerizing version and $0.1 \%$ in the heat-polymerizing form ${ }^{1}$. The presence of these free monomers has an impact on surface roughness and complicates the resin finishing and polishing process.

A greater accumulation of biofilm is frequently observed on irregular surfaces and also causes discomfort to the patient. The biofilm, considered to be a bacterial microcolony, adheres to irregular surfaces in the mouth and they grow, forming a continuous layer of bacteria that adversely affects dental structures and oral tissue ${ }^{3}$. The accumulated biofilm is related to the etiology of diseases such as dental caries and periodontal diseases ${ }^{4}$. Accordingly, prosthetic work needs to have a smooth, well-finished surface in order to minimize the accumulation of bacteria. According to Kasina et al. ${ }^{5}$, a porous prosthetic part is vulnerable to exogenous coloration, the deposition of tartar and adhering substances. Thus, for a prosthetic appliance to be hygienically acceptable, it must not be porous. The fabrication of temporary crowns is a hugely important step in prosthetic treatment, mainly in the case of lengthy treatment. Among other characteristics, the temporary element should not retain biofilm as this may cause constant inflammation of the gums, thereby hindering the clinical stages for the production of the definitive crown.

In view of this, in order to avoid the loss of prosthetic pillars and adjacent teeth to periodontal disease or caries, smooth well-finished parts are extremely important, in addition to making the element esthetically acceptable ${ }^{6-7}$. Thus, finishing and polishing techniques need to be established reconciling the use of accessible materials, reduction in clinical time and the attainment of less surface roughness ${ }^{6}$.
Accordingly, in order to achieve adequate surface smoothness, there are two forms of finishing and polishing that are most commonly used in clinical practice. The more conventional method is the finishing and polishing done with the use of maxicut and minicut burs, mounted stones, a mandrel with fabric sandpapers and grinding wheels (with pumice stone and water) and cotton sandpaper (with Spanish white and water). At the present time, the use of the Dhpro ${ }^{\circledast}$ Finishing and Polishing Kit is the recommended option, which has rubber tips (silicone) and rotary brushes (Scotch Brite - goat-hair, cotton or felt) with a sequence of use recommended by the manufacturer.

Although autopolymerizing acrylic resin is widely used in the fabrication of temporary restorations, there is little information in the literature about the effect of certain finishing and polishing techniques on surface texture or on which resins the techniques produce the best results. In view of this, the present study was proposed with the aim of analyzing surface roughness of samples prepared with two commercial brands of autopolymerizing resin, applying two finishing and polishing methods, ascertaining which method is most effective for each type of resin.

\section{METHODS}

In this experiment, classified as a controlled in vitro experimental study, two brands of autopolymerizing acrylic resin were used that are widely employed in the fabrication, repair and relining of temporary crowns, namely:

- Clássico Dencor ${ }^{\circledR} 62$

- Duralay ${ }^{\circledR} 62$

\section{Fabrication of test specimens}

In the course of this study, in order to obtain the specimens, aluminum expulsion molds were fabricated measuring $65 \times 12 \mathrm{~mm}$ at the top, $64 \times 11 \mathrm{~mm}$ at the base and with a thickness of $3.5 \mathrm{~mm}^{8}$. A quantity of Zetalabor ${ }^{\circledR}$ Zhermak Condensation Silicon was put in a plastic container and molds were produced from the aluminum dies. The acrylic resins were manipulated using the proportions recommended by the manufacturer. During the plastic phase (working phase) the resins were accommodated, with the use of finger pressure, in the condensation silicone molds. Once completely polymerized, the specimens were removed from the molds. Twenty test specimens were fabricated (10 of each make) and each was split down the middle, each half receiving a different type of finishing and polishing (Figure 1). 


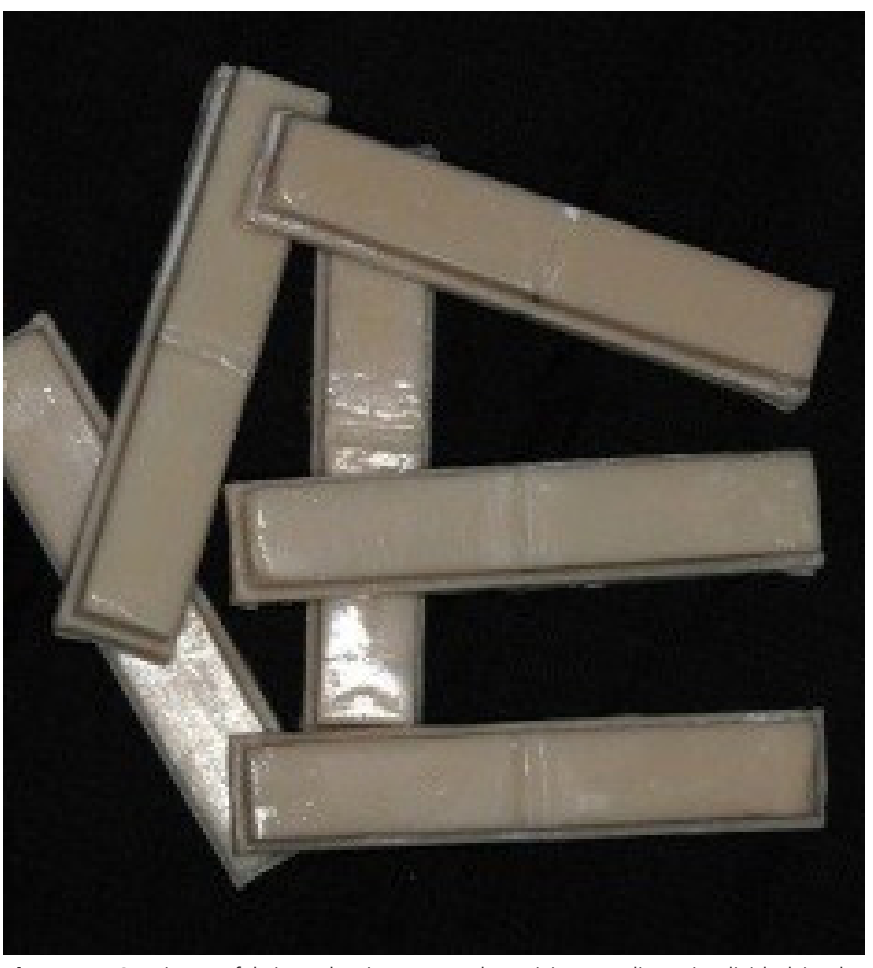

Figure 1. Specimens fabricated using autopolymerizing acrylic resin divided in the middle.

\section{Finishing and polishing techniques}

The method considered to be conventional, which has the following sequence: tungsten grinders (Maxicult); cylindrical carborundum mounted stone; 180 grit sandpaper for wood finishing in $10 \mathrm{~mm}$ strips, mounted on a mandrel; fabric disc on a lathe using a mixture of pumice stone and water as the abrasive; lastly, cotton disc on a lathe with "Spanish white" polisher and water;

Dhpro ${ }^{\circledR}$ finishing and polishing kit comprising: Maxicut (for greater abrasion), Minicut (for smaller degree of abrasion), a reasonable amount of abrasion with rubber tips (Grey $\rightarrow$ Green $\rightarrow$ Yellow), Scotch Brite wheel (to remove scratches), goat-hair brush, felt wheel (goat-hair brush and felt wheel are both used with the FotoAcrill ${ }^{\circledR}$ paste that comes with the kit) and, lastly, the cotton brush is used to remove excess paste.

Each stage of the finishing and polishing methods lasts 10 seconds.

\section{Data acquisition and statistical analysis}

The fabrication of the test specimens and the finishing and polishing procedures listed above were carried out by a single operator. The test specimens were subsequently subjected to an evaluation of surface roughness using the Taylor Hobson Surtronic 25 roughness tester, in the technology center in the Metrology laboratory at the Rio Grande do Norte Federal University, providing 40 sets of roughness results, each result composed of three arithmetic mean readings. The readings were taken perpendicularly to the direction of the finishing and polishing. The data collected in the roughness test were subjected to the Student's t-test.

\section{RESULTS}

In the t-test, a significant difference was found between conventional polishing and the polishing with the DhPro ${ }^{\circledR}$ kit (Figure $2 / p<0.001$ ), but this discrepancy is not related to the make of the resins. Table 1 shows that the makes of acrylic resin, when compared, and without taking into account the type of polishing, possess similar mean roughness values. By analyzing the best polishing for each make of acrylic resin, the conventional method was shown to be superior (Figure 3).

Table 1. Roughness, correlating the two makes of resin (Clássico Dencor $^{\circledR}$ and Duralay ${ }^{\circledR}$.

\begin{tabular}{cccccc}
\hline $\begin{array}{c}\text { Type of } \\
\text { Resin }\end{array}$ & $\mathrm{N}$ & $\begin{array}{c}\text { Mean } \\
(\mu \mathrm{m})\end{array}$ & $\begin{array}{c}\text { Std. } \\
\text { Deviation }\end{array}$ & "t" & "p" \\
\hline \multirow{2}{*}{ Roughness } & Clássico & 20 & 0.16500 & 0.063398 & $\begin{array}{c}0.052 \\
0.959\end{array}$ \\
& $\begin{array}{c}\text { Dencor } \\
\text { Duralay }\end{array}$ & 20 & 0.16635 & 0.096309 & \\
\hline
\end{tabular}

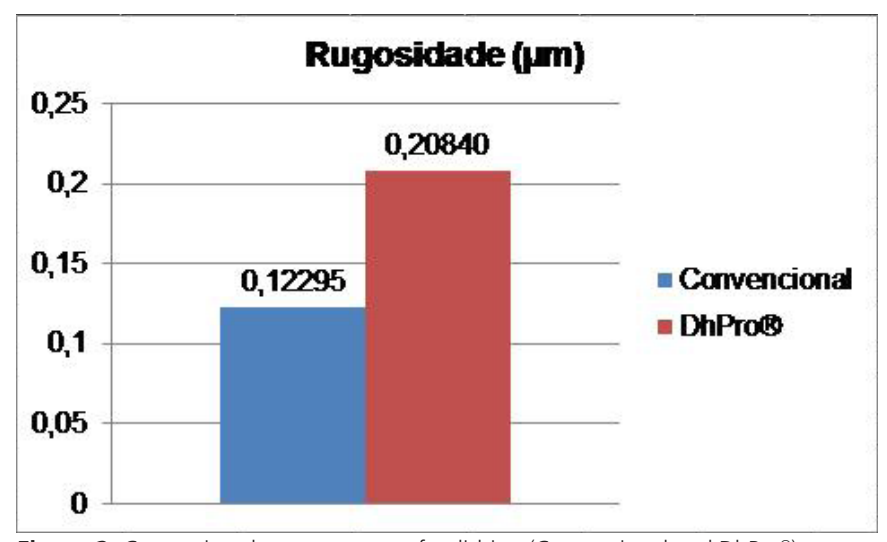

Figure 2. Comparison between types of polishing (Conventional and DhPro ${ }^{\oplus}$ ).

\section{DISCUSSION}

The interrelationship between the transitional and definitive stages of fixed prosthetic treatment is very significant ${ }^{2}$. For this reason, temporary prostheses should be 
Rugosidade ( $(\mathbf{m})$

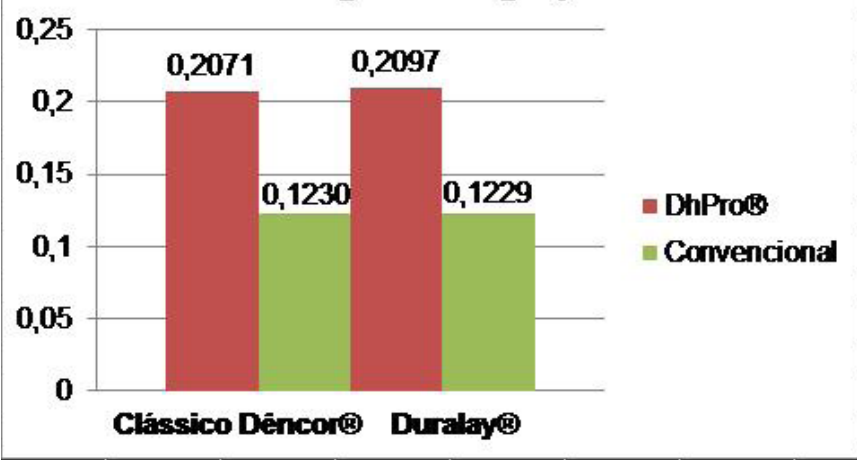

Figure 3. Comparison of the polishing of each acrylic resin (Clássico Dencor ${ }^{\circledR}$ and Duralay ${ }^{\circledR}$ ) versus Conventional and DhPro ${ }^{\circledR}$ polishing - Page 10.

perfectly in accordance with what is desired of the definitive prosthesis. In view of this, the surface of these temporary restorations should be polished to avoid accumulation of biofilm, as well as to provide comfort for the patient and be esthetically acceptable?

A number of authors devised a roughness classification in which they determined the range from 0.7 $\mu \mathrm{m}$ to $3.4 \mu \mathrm{m}$ as the values of low roughness ${ }^{9}$. Accordingly, all surface roughness values obtained using the techniques of finishing and polishing used in the present study can be considered low, as the surface roughness values found varied between $0.08 \mu \mathrm{m}$ and $0.48 \mu \mathrm{m}$. On the other hand, Quirynem \& Bollen et al. ${ }^{10}$ stated that the roughness value below which bacterial adherence should not be expected, thus making the prosthesis clinically acceptable, is $0.2 \mu \mathrm{m}$. Consequently, it can be shown that the mean values of roughness exhibited in this study, for both types of polishing, and mainly with conventional polishing as it achieved lower mean values, should not generate an accumulation of microorganisms.

Mesquita et al. ${ }^{11}$ evaluated the effect on surface roughness of conventional and chemical polishing on heatactivated and autopolymerizing acrylic resin specimens. The results confirmed that conventional polishing was more effective than chemical polishing in reducing roughness. Several authors reported that chemical polishing on autopolymerizing acrylic resin structures causes softening

\section{REFERENCES}

1. Bahrani F, Safari A, Vojdani M, Karampoor G. Comparison of hardness and surface roughness of two denture bases polymerized by different methods. World J Dent. 2012; 3(2):171-5. doi: 10.1111/jopr.12605 of the less polymerized structures, caused by the monomer used in this type of polishing ${ }^{12}$. The advantage of this type of polishing is the speed and ease of execution, but it is seen to be less effective than mechanical methods ${ }^{13}$.

Another form of mechanical polishing employed by dental surgeons is to use Sof Lex ${ }^{\circledast}(3 \mathrm{M})$ discs. When compared to methods such as rubber cup + Vaseline; pumice stone + Spanish White on a polishing lathe; 150 grit grinding discs for mandrel, the Sof $\operatorname{Lex}^{\circledR}(3 \mathrm{M})$ discs produced the best results in reducing surface roughness, with a mean value of $0.48 \mu \mathrm{m}^{14}$. This demonstrates the superior efficiency of the methods employed in this study, principally the conventional method.

The time taken to complete the polishing was evaluated, showing that, although many easy-to-use finishing and polishing kits are available, the method which takes the least amount of time, conventional polishing with a mechanical lathe, is superior ${ }^{4}$.

\section{CONCLUSIONS}

According to the methodology and data analysis used in this study, it was possible to draw the following conclusions:

a) Conventional polishing is more effective in reducing the surface roughness of the two acrylic resins in comparison with the DhPro ${ }^{\circledR}$ kit;

b) With regard to the two makes of acrylic resin, there is no significant difference between the mean values for surface roughness.

\section{Collaborators}

GLC DUARTE performed the data collection, carried out the laboratory tasks and also helped to draft the scientific article. AKP MENDONÇA AND ARA FREITAS drafted the scientific article and submitted the study for publication. ARC DUARTE AND JCP HOLANDA carried out the development of the methodology and supervision of the present study. The authors declare there are no conflicts of interest in the present study.

2. Barbosa DGO, Montenegro AC, Duarte JLP. Avaliação da rugosidade superficial de três resinas acrílicas para restauração provisória submetidas a diferentes métodos de polimento. Rev Bras Odontol. 2013;70(2):152-5. doi: s003472722013000200011

3. Neppelenbroek KH, Pinto ECT, Pavarina AC, Vergani CE, Jorge $\mathrm{JH}$, Almilhatti HJ. Aderência de microorganismos em materiais 
para basede próteses. Rev Odontol Univ Cidade São Paulo. 2009;21(2):126-36.

4. Berger JC, Driscoll CF, Romberg E, Luo Q, Thompson G. Surface roughness of denture base acrylic resins after processing and after polishing. J Prosthodont. 2006;15(3):180-6.

5. Kasina SP, Ajaz T, Attili S, Surapaneni H, Cherukuri M, Srinath HP. To evaluate and compare the porosities in the acrylic mandibular denture bases processed by two different polymerization techniques, using two different brands of commercially available denture base resins - an in vitro study. J Int Oral Health. 2014; 6(1):72-77.

6. Goncalves TS, Spohr A, Souza RM, Menezes LM. Surface roughness of auto polymerized acrylic resin according to different manipulation and polishing methods. Angle Orthod. 2008;78(5):931-4. doi: 10.2319/080307-363.1

7. Barbosa GKS, Zavanelli AC, Guilherme AS, Zavanelli RA. Efeito de diferentes técnicas de acabamento e polimento sobre a rugosidade superficial de resinas acrílicas utilizadas para restaurações provisórias. Cienc Odontol Bras. 2009;12(1):1522. doi: 10.14295/bds.2009.v12i1.248

8. Duarte $A R C, A Y \cup B$ E, Bonachela $W$, Salvador M, Vieira L. Avaliação de rugosidade superficial e resistência flexional de quatro resinas acrílicas utilizadas para próteses sobre implante, em função imediata. UFES Rev Odontol Vitória. 2006;8(1):3745.

9. Zissis AJ, Polyzois GL, Yannikakis SA, Harrison A. Roughness of denture materials: a comparative study. Int J Prosthodont. 2000;13(2):136-140. doi: 10.1111/j.1365-2842.1987. tb00713.x
10. Quirynen $M$, Bollen CM. The influence of surface roughness and surface-free energy on supra- and subgingival plaque formation in man. A review of the literature. J Clin Periodontol. 1995;22(1):1-14. doi: 10.1111/j.1600-051X.1995.tb01765.x

11. Mesquita FM, Domitti SS, Consani XLR, Consani S. Efeito do polimento químico sobre a rugosidade superfacial de resinas acrílicas ativadas química e termicamente em diferentes períodos de armazenagem. Rev Fac Odontol Univ Passo Fundo. 2000;5(2):51-4

12. Mesquita FM, Domitti SS, Cardoso LAM. Efeito do polimento químico sobre a rugosidade superficial das resinas acrílicas. RGO, Rev Gaúch Odontol. 2001;49(2):98-101.

13. Braun KO, Pellegrin DZ, Coradini L, May LG. Análise da rugosidade superficial de resinas acrílicas para coroas provisórias submetidas a diferentes tipos de polimento. RFO UPF. 2006;11(2):41-44. doi: 10.5335/rfo.v11ii2.1114

14. Seabra EJG, Lima IPC, Matsuno PM, Paiva ACS. Rugosidade superficial da resina acrílica frente a quatro diferentes técnicas de polimento. RGO, Rev Gaúch Odontol. 2011;59(1):45-50.

Received on: 8/12/2016

Final version resubmitted on: 24/4/2017

Approved on: 20/6/2017 